\title{
Sulfation Roasting Mechanism for Spent Lithium-Ion Battery Metal Oxides Under $\mathrm{SO}_{2}-\mathrm{O}_{2}$-Ar Atmosphere
}

\author{
JUNJIE SHI (D) ${ }^{1,2}$ CHAO PENG, ${ }^{1,3}$ MIN CHEN, ${ }^{1}$ YUN LI, ${ }^{1}$ \\ HURMAN ERIC ${ }^{1}$ LASSI KLEMETTINEN,${ }^{1}$ MARI LUNDSTRÖM,${ }^{1}$ \\ PEKKA TASKINEN,${ }^{1}$ and ARI JOKILAAKSO ${ }^{1,4}$
}

\begin{abstract}
1.-Department of Chemical and Metallurgical Engineering, School of Chemical Engineering, Aalto University, Kemistintie 1F, P.O. Box 16100, 02150 Espoo, Finland. 2.-e-mail: junjieshi@126.com. 3.—e-mail: chao.peng@aalto.fi. 4.—e-mail: ari.jokilaakso@aalto.fi
\end{abstract}

\begin{abstract}
Sulfation roasting followed by water leaching has been proposed as an alternative route for recycling valuable metals from spent lithium-ion batteries (LIBs). In the present work, the reaction mechanism of the sulfation roasting of synthetic $\mathrm{LiCoO}_{2}$ was investigated by both thermodynamic calculations and roasting experiments under flowing $10 \% \mathrm{SO}_{2}-1 \% \mathrm{O}_{2}-89 \% \mathrm{Ar}$ gas atmosphere at $700^{\circ} \mathrm{C}$. The products and microstructural evolution processes were characterized by x-ray diffraction, scanning electron microscope and energy dispersive $\mathrm{x}$-ray spectrometer, and atomic absorption spectroscopy. It was confirmed that $\mathrm{Co}_{3} \mathrm{O}_{4}$ was formed as an intermedia product, and the final roasted products were composed by $\mathrm{Li}_{2} \mathrm{SO}_{4}, \mathrm{Li}_{2} \mathrm{Co}\left(\mathrm{SO}_{4}\right)_{2}$, and $\mathrm{CoO}$. The leaching results indicated that $99.5 \% \mathrm{Li}$ and $17.4 \%$ Co could be recovered into water after 120 min of roasting. The present results will provide the basis and solid guidelines for recycling of $\mathrm{Li}$ and Co from spent LIBs.
\end{abstract}

\section{INTRODUCTION}

The circular economy has become a hot topic worldwide during recent years. It requires the circulation of materials and energy, especially recycling from secondary resources. ${ }^{1}$ During the last 20 years, a huge amount of spent lithium-ion batteries (LIBs) has been generated as a result of the increasing consumption of LIBs since their commercialization by SONY Inc. in $1991 .^{2}$ The amount of battery waste will increase exponentially as the batteries of electric vehicles (EV) come into end of life. In 2017, nearly 1.1 million EVs were sold worldwide, whereas in 2025 the amount will be ca. 11 million. Consequently, the predicted global amounts of battery metals ending up in recycling in 2035 will be ca. 104 GWh (with 8 years first life and 5 years second life for $70 \%$ of batteries), corresponding to ca. $7.5 \mathrm{kt} \mathrm{Li}$ and $12 \mathrm{kt} \mathrm{Co.}{ }^{3,4}$

Spent LIBs can be treated as valuable secondary sources of metals because of their large amounts of $\mathrm{Li}, \mathrm{Co}, \mathrm{Ni}, \mathrm{Mn}, \mathrm{Cu}, \mathrm{Al}$, and $\mathrm{Fe},{ }^{5,6}$ which are present in higher concentration than in natural primary ores. $^{7}$ Typically, a spent Li-ion battery contains $5-$ 20 wt.\% Co, 5-7 wt.\% Li, 5-7 wt.\% Ni, 15 wt.\% organics, and 7 wt.\% plastics. ${ }^{8}$ However, only about $5 \%$ of spent portable LIBs are recycled today, and LIB production will suffer a global supply shortage of key elements including $\mathrm{Li}, \mathrm{Co}$, and $\mathrm{Ni}$ due to the increasing demand for consumer electronic devices and EVs. ${ }^{9}$ On the other hand, if the spent LIBs are not treated properly, they will cause serious environmental pollution such as soil and groundwater contamination by the leakage of electrolytes such as lithium hexafluorophosphate $\left(\mathrm{LiPF}_{6}\right)$ if they are burned or exposed to air or water. ${ }^{10,11}$ Therefore, the recycling of spent LIBs is necessary to alleviate the unprecedented demand for raw materials for the synthesis of LIBs as well as environmental and economic benefits.

Currently, the worldwide spent LIB recycling technologies can be classified into hydrometallurgy, pyrometallurgy, or their combination.,12 In the hydrometallurgical processes, the spent LIBs first need to be pretreated to enrich the target metals, e.g., by discharging, dismantling, crushing, etc., ${ }^{13-15}$ and then dissolved into inorganic acids or organic acids. ${ }^{16-21}$ The resultant Co, Li-rich acidic leaching solution is then subjected to the subsequent purification and recovery process, for 
instance, chemical precipitation, ${ }^{22}$ solvent extraction, ${ }^{23}$ or ion-exchange ${ }^{24}$ methods. Nonetheless, these hydrometallurgy technologies involve high levels of chemical consumption, weak adaptability to input materials, and high risk of fire or explosion during the discharging process. ${ }^{25}$ In contrast, pyrometallurgical technology such as smelting does not need an additional discharging process and exhibits strong adaptability to input materials. The high-temperature smelting process has been industrially utilized by various companies (e.g., Toxco Inc., USA; Sony Corp., France), through which Co and $\mathrm{Ni}$ can be recovered as alloys, whereas the majority of $\mathrm{Li}$ is ready to end up within the slag fraction and dusts. ${ }^{26-28}$

Considering the abovementioned shortcomings of the hydrometallurgy and pyrometallurgy methods, researchers are starting to look for combined methods to treat LIBs waste, e.g., by nitration roasting, ${ }^{18}$ sulfation roasting, ${ }^{29}$ reduction roasting with carbon, ${ }^{30}$ or vacuum evaporation ${ }^{31}$ followed by water leaching. Among these methods, sulfation roastingwater leaching is considered one of the most promising as this process has been extensively investigated for the extraction of valuable metals such as $\mathrm{Cu}, \mathrm{Ni}, \mathrm{Co}, \mathrm{V}$, and $\mathrm{Mn}$ from different primary and secondary ores including pyrite, nickel sulfide ore, copper concentrate, and lepidolite. ${ }^{32-35}$ The core concept of this method is to selectively transfer the desired metals (e.g., Co and $\mathrm{Li}$ ) into soluble sulfates, but leave the other unwanted impurities as insoluble oxides. A recent study by Wang et al. ${ }^{36}$ revealed that Li could be selectively extracted from spent LIBs via an indirect sulfation roasting process with the $\mathrm{SO}_{3}$ gas generated by the decomposition of $\mathrm{NaHSO}_{4} \cdot \mathrm{H}_{2} \mathrm{O}$. However, the mechanism of the sulfation roasting process is still unclear, and more efforts are needed to fully understand it.

In the present work, sulfation roasting followed by water leaching is proposed for the recycling of spent LIBs, and the reaction mechanism under $\mathrm{SO}_{2^{-}}$ $\mathrm{O}_{2}$ atmosphere will be elaborated from both the thermodynamic and experimental aspects. The novelty of this process is not only an alternative method for handling spent LIBs, their lithium, and base metals, but also an option for recovering rare earth elements such as sulfates. ${ }^{37}$

\section{MATERIALS AND METHODS}

\section{Materials}

To clarify the recycling mechanism of active materials present in spent LIBs under $\mathrm{SO}_{2}-\mathrm{O}_{2}$ atmosphere, synthetic $\mathrm{LiCoO}_{2}$ powder with a purity of $\geq 97$ wt.\% (Alfa Aesar, Germany) was selected as a compound representing the typical cobalt-rich component of spent LIBs. $\mathrm{LiCoO}_{2}$ powder was first dried at $120^{\circ} \mathrm{C}$ for $24 \mathrm{~h}$ to evaporate the water and other volatiles. For each experiment, an initial amount of $4.00 \mathrm{~g}\left(m_{0}\right) \mathrm{LiCoO}_{2}$ powder was weighed (by $0.0001 \mathrm{~g}$ balance) and uniformly distributed in the silica crucible ( $130 \mathrm{~mm}$ long, $30 \mathrm{~mm}$ wide, $9.5 \mathrm{~mm}$ high, $3.5 \mathrm{~mm}$ thick) for further steps.

\section{Sulfation Roasting Experiments}

Sulfation roasting experiments were carried out in a horizontal tube furnace (Fig. 1). The silica crucible containing $\mathrm{LiCoO}_{2}$ powder was slowly pushed into the hot zone, and the temperature was measured by a $K$-type thermocouple and controlled by a Keithley 2000 multimeter intelligent temperature controller (accuracy of $\pm 1^{\circ} \mathrm{C}$, Tektronix, Inc., Beaverton, OR, USA). After the temperature of the crucible reached the target value, a pre-roasting experiment was first conducted for sample S1 under $400 \mathrm{~mL} / \mathrm{min}$ Ar (99.999\%, AGA, Finland) atmosphere. Thereafter, samples S2 to S12 were employed to be roasted under $\mathrm{SO}_{2}-\mathrm{O}_{2}-\mathrm{Ar}$ gas mixture with a total flow rate of $400 \mathrm{~mL} / \mathrm{min}$. The gas composition was achieved by mixing $\mathrm{SO}_{2}$ (99.99\%) and $\mathrm{O}_{2}(99.99 \%)$ with $\mathrm{Ar}$ (99.999\%) (AGA, Finland). The flow rates of these gases were controlled by DFC digital mass flow meters (Aalborg, USA). The offgas was cleaned by $\mathrm{NaOH}$ solution with BTS as an indicator (bromothymol blue, $\mathrm{C}_{27} \mathrm{H}_{28} \mathrm{Br}_{2} \mathrm{O}_{5} \mathrm{~S}$, Sigma-Aldrich, USA) to remove $\mathrm{SO}_{2}$ before venting to the fume hood.

After the preset roasting time, the silica crucible was quickly removed from the furnace and cooled in air. The reacted product after sulfation roasting $\left(m_{1}\right)$ was accurately weighed to calculate the weight increase $\Delta m\left(\Delta m=m_{1}-m_{0}, \mathrm{~g}\right)$ and relative weight increase $\alpha\left(\alpha=\Delta m / m_{0}, \%\right)$.

\section{Analytical Methods}

The roasted products were leached with water at $25^{\circ} \mathrm{C}$ for $60 \mathrm{~min}$ to produce a leachate and leach residues under the conditions of a solid/liquid ratio of $100 \mathrm{~g} / \mathrm{L}$. After the leaching step, the leachate was separated by centrifugation at $4000 \mathrm{rpm}$ for $10 \mathrm{~min}$ $(\mathrm{S} / \mathrm{L})$ at room temperature. The leach residue was then fully digested by nitrohydrochloric acid to analyze the chemical composition. After proper dilution, solutions from the leachate and residue were analyzed by atomic absorption spectroscopy (AAS, Varian AA240, Agilent Technologies, CA, USA) to determine the concentrations of $\mathrm{Li}$ and $\mathrm{Co}$.

The roasted samples and leach residues were characterized by x-ray diffraction (XRD, PANalytical X'Pert Pro Powder, Almelo, The Netherlands) using $\mathrm{Co} K \alpha$ radiation at a scan rate of $2 \%$ min from $15^{\circ}$ to $90^{\circ}$ (acceleration potential $40 \mathrm{kV}$, current $30 \mathrm{~mA}$ ). Quantitative phase composition of the XRD results was performed by HighScore Plus 4.1 software (PANalytical) using Rietveld fitting, based upon the PDF2 powder database. ${ }^{38}$ Meanwhile, the microstructures of phases were analyzed using a Tescan MIRA 3 scanning electron microscope (SEM, Tescan, Brno, Czech Republic) equipped with an UltraDry Silicon Drift energy-dispersive x-ray 


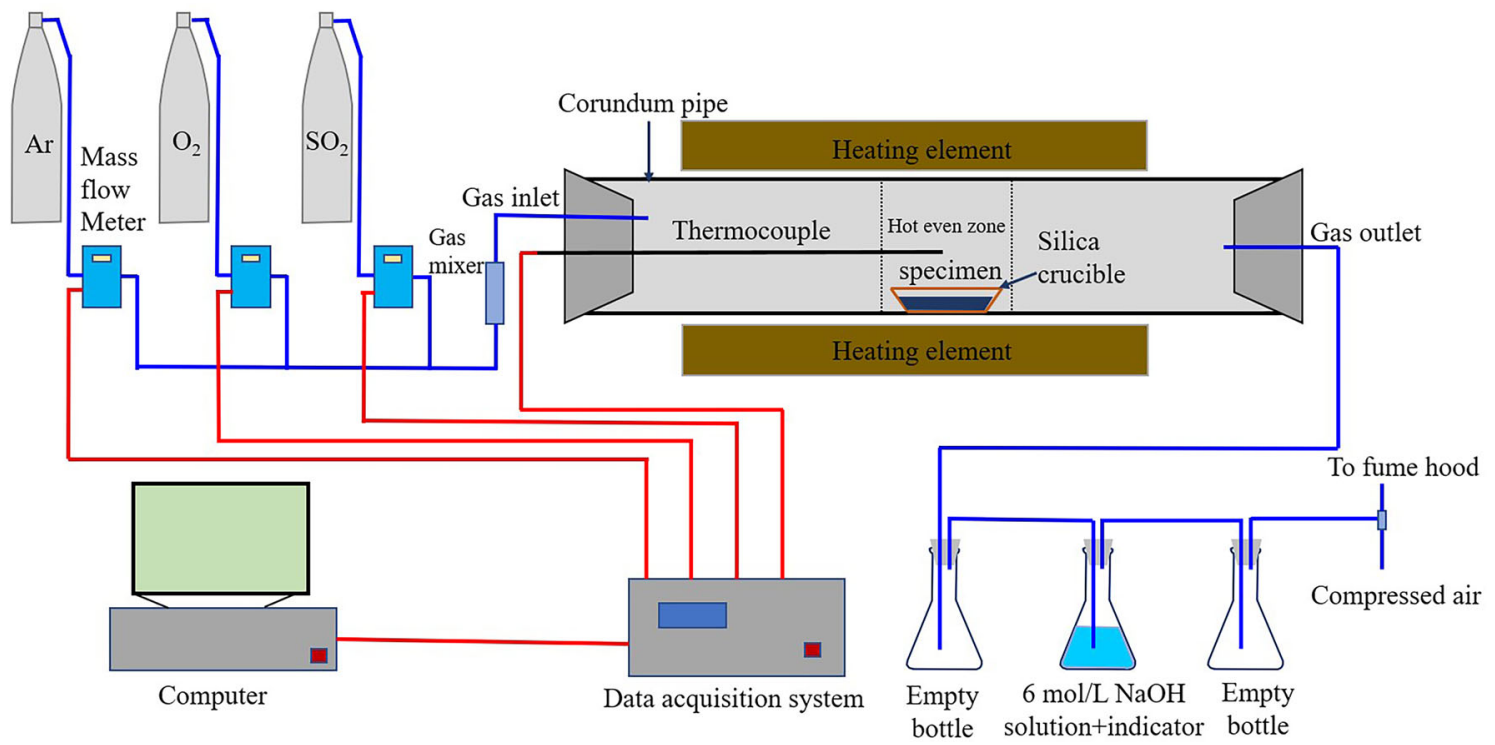

Fig. 1. Schematic of the sulfation roasting experimental setup.

spectrometer and NSS microanalysis software (EDS, Thermo Fisher Scientific, Waltham, MA, USA). An accelerating voltage of $5 \mathrm{kV}$ and beam current of $10 \mathrm{nA}$ were employed for the SEM analysis, while for the EDS detection, an accelerating voltage of $15 \mathrm{kV}$ and a beam current of $20 \mathrm{nA}$ were used. Proza (Phi-Rho-Z) matrix correction procedure $^{39}$ was employed for raw data processing, and the standards utilized in EDS analyses were metal Co (for $\mathrm{Co}, \mathrm{L} \alpha$ ), quartz (for $\mathrm{O}, \mathrm{K} \alpha$ ), and marcasite (for $\mathrm{S}, \mathrm{K} \alpha$ ).

\section{Thermodynamic Calculations}

Nowadays, commercial thermodynamic software such as HSC $^{40}$ has been developed to make predictions of complex reactions for oxide and sulfide systems. In the present work, HSC Chemistry $9^{41}$ was employed to calculate the equilibrium assemblages for the Li-Co-S-O system.

\section{RESULTS AND ANALYSIS}

\section{Thermodynamics}

The formation of sulfate can be described by the reactions of oxide in $\mathrm{SO}_{2}-\mathrm{O}_{2}$ gas mixtures or $\mathrm{SO}_{3}$ gas atmosphere, as shown in Eqs. 1, 2, and 3.

$$
\begin{gathered}
\mathrm{MO}_{x}(\mathrm{~s})+0.5 x \mathrm{O}_{2}(\mathrm{~g})+x \mathrm{SO}_{2}(\mathrm{~g})=\mathrm{M}\left(\mathrm{SO}_{4}\right)_{x}(\mathrm{~s}) \\
2 \mathrm{SO}_{2}(\mathrm{~g})+\mathrm{O}_{2}(\mathrm{~g})=2 \mathrm{SO}_{3}(\mathrm{~g}) \\
\mathrm{MO}_{x}(\mathrm{~s})+x \mathrm{SO}_{3}(\mathrm{~g})=\mathrm{M}\left(\mathrm{SO}_{4}\right)_{x}(\mathrm{~s})
\end{gathered}
$$

Therefore, the stability of the sulfates of interest was calculated by HSC and is shown in Fig. 2 as the predominance area diagram of the Li-Co-O-S system, at temperatures from $600^{\circ} \mathrm{C}$ to $800^{\circ} \mathrm{C}$. It is

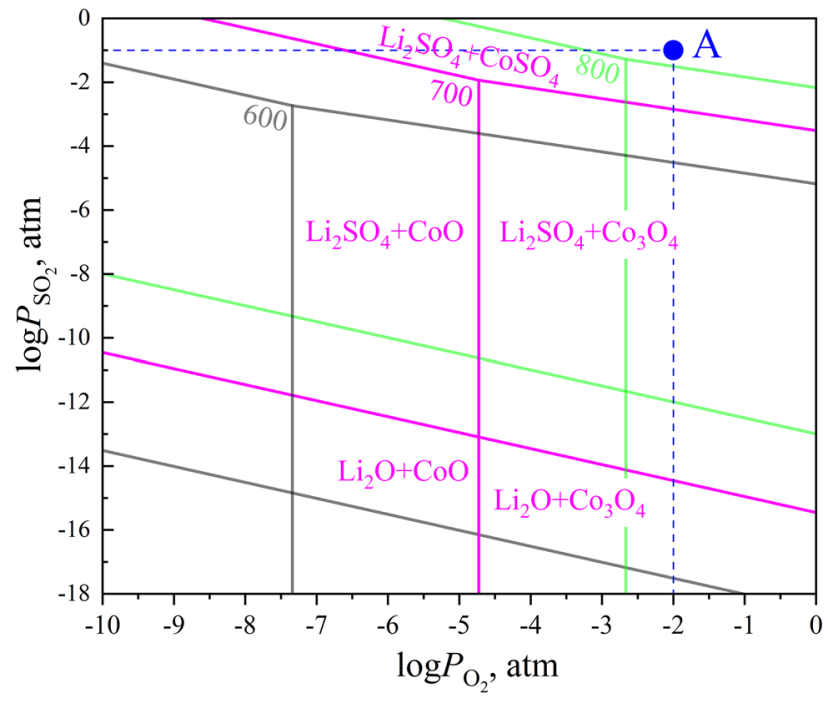

Fig. 2. Predominance area diagram obtained by superimposing $\mathrm{Li}-$ S-O and Co-S-O diagrams from $600^{\circ} \mathrm{C}$ to $800^{\circ} \mathrm{C}$.

clear that $\mathrm{Li}_{2} \mathrm{SO}_{4}$ is stable at higher $\mathrm{SO}_{2}$ and $\mathrm{O}_{2}$ partial pressures from $600^{\circ} \mathrm{C}$ to $800^{\circ} \mathrm{C}$, while $\mathrm{Co}$ may exist as $\mathrm{CoO}, \mathrm{Co}_{3} \mathrm{O}_{4}$, and $\mathrm{CoSO}_{4}$ in different $\mathrm{O}_{2}$ and $\mathrm{SO}_{2}$ partial pressures. Accordingly, the predominance area diagram could also be divided into five phase combination domains at a fixed temperature, i.e., $\quad \mathrm{Li}_{2} \mathrm{SO}_{4}+\mathrm{CoSO}_{4}, \quad \mathrm{Li}_{2} \mathrm{SO}_{4}+\mathrm{CoO}$, $\mathrm{Li}_{2} \mathrm{SO}_{4}+\mathrm{Co}_{3} \mathrm{O}_{4}, \quad \mathrm{Li}_{2} \mathrm{O}+\mathrm{CoO}$, and $\mathrm{Li}_{2} \mathrm{O}+\mathrm{Co}_{3} \mathrm{O}_{4}$. This means that a selective sulfation or co-sulfation roasting can be achieved by adjusting the operational point in the roaster. As a result, the experimental condition with an atmosphere of $10 \% \mathrm{SO}_{2}$ and $1 \% \mathrm{O}_{2}$ at $700^{\circ} \mathrm{C}$ (point $\mathrm{A}$ in Fig. 2) was selected for the sulfation roasting experiments to explore the reaction mechanism. 
(a)

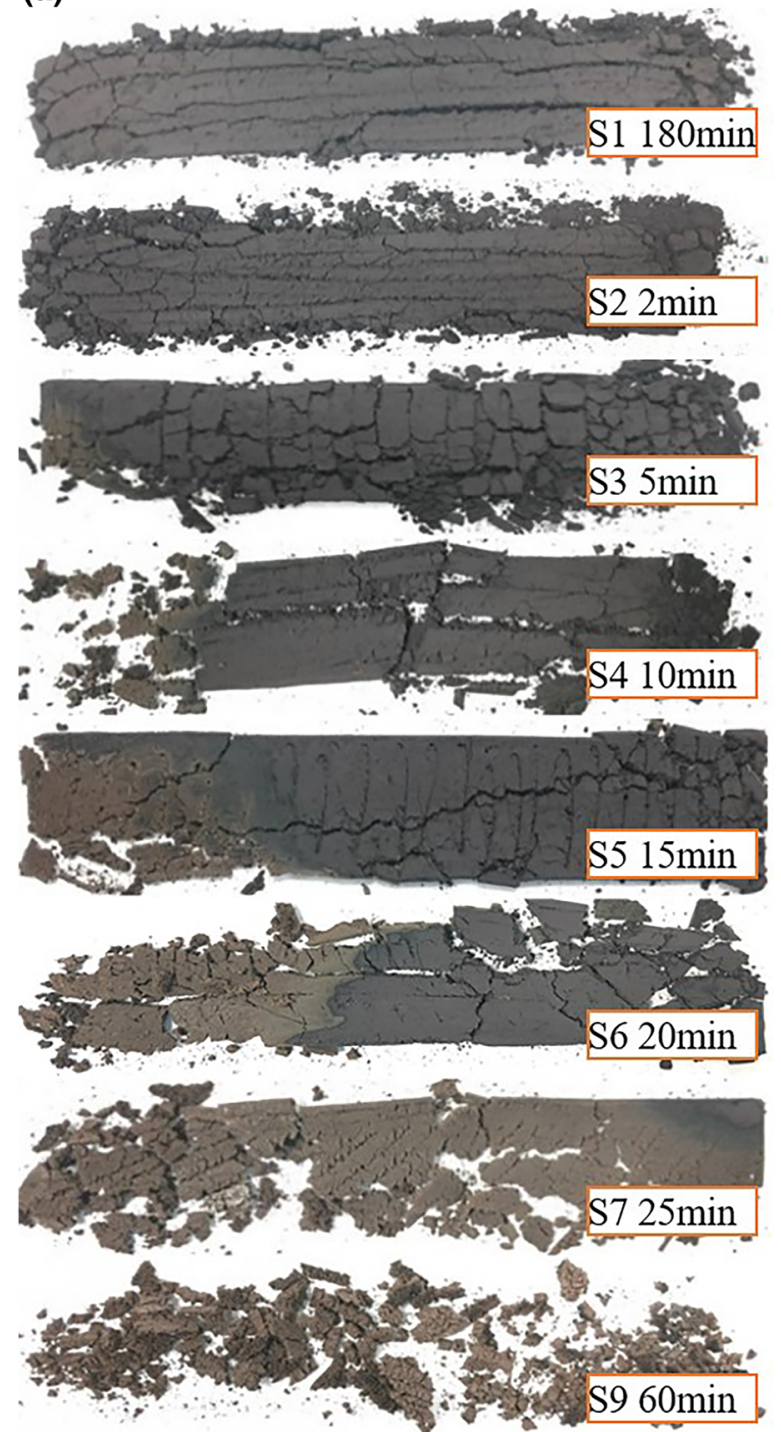

(b)

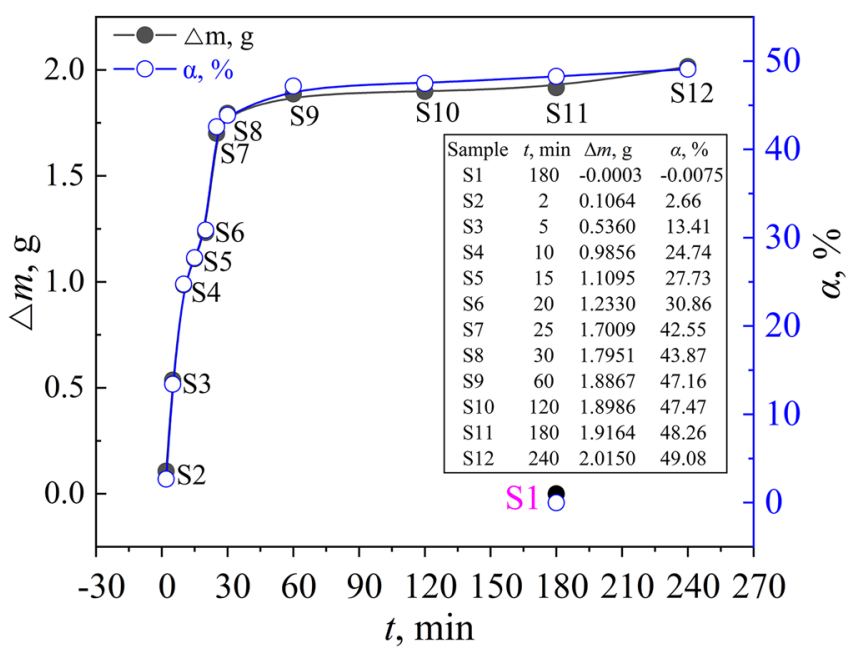

(c)

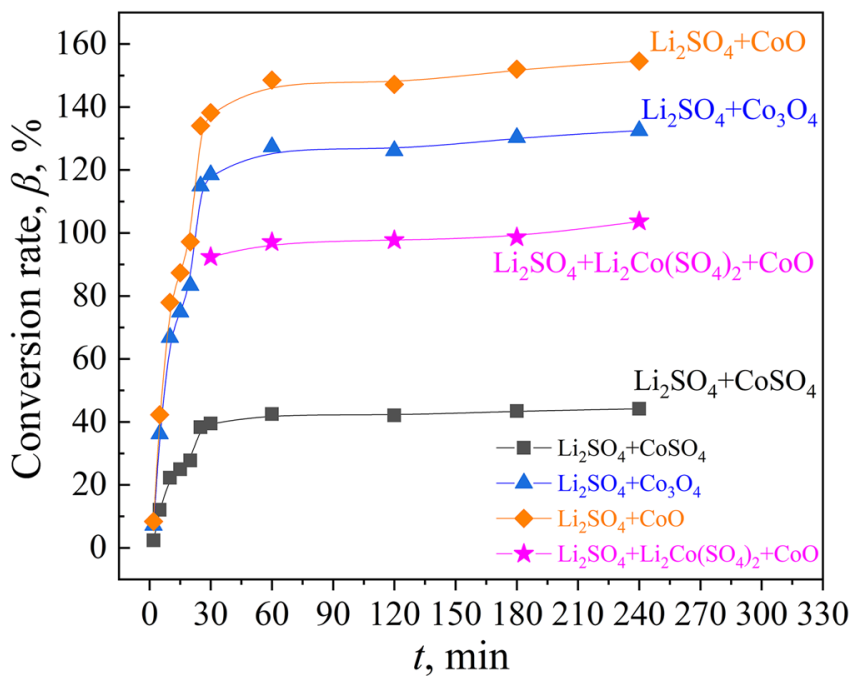

Fig. 3. Macrograph of color evolution, weight change $\left(\Delta m\right.$ and $\alpha$ ), and conversion during sulfation roasting at $700^{\circ} \mathrm{C}$. (a) Macrographs; (b) $\Delta m$ and $\alpha$; (c) conversion ratio, $\beta$.

\section{Macrophotograph and Weight Difference}

The macrographs after sulfation roasting experiments under a $10 \% \mathrm{SO}_{2}-1 \% \mathrm{O}_{2}-89 \% \mathrm{Ar}$ atmosphere at $700^{\circ} \mathrm{C}$, as well as the weight differences (weight increase $\Delta m$ and relative weight increase $\alpha$ ) and the conversion ratios, are presented in detail in Fig. 3. Before the sulfation roasting experiment, a roasting pre-experiment was carried out for sample S1 under $400 \mathrm{~mL} / \mathrm{min} \mathrm{Ar}$ atmosphere at $700^{\circ} \mathrm{C}$ with $180 \mathrm{~min}$. Both the macrophotograph in Fig. $3 \mathrm{a}$ and the weight difference in Fig. $3 \mathrm{~b}$ indicate that there was no reaction during the process, and sample $\mathrm{S} 1$ still presented the original powder state compared with the raw material.

For samples S2 to S9, the color change in Fig. 3a clearly suggested that the sulfation roasting reaction continuously proceeded with time, extending from $2 \mathrm{~min}$ to $60 \mathrm{~min}$. A light-yellow color could be observed at the left corner of sample S3 when the roasting time was increased to $5 \mathrm{~min}$, while the other parts of sample S3 still kept the original color compared with the raw $\mathrm{LiCoO}_{2}$ powder. Thereafter, the color changed gradually from the left to right side along with the gas flow direction when the time was increased from $5 \mathrm{~min}$ to $25 \mathrm{~min}$, and only a small part at the right corner of the sample kept the original color at $25 \mathrm{~min}$. When the time was further increased to $60 \mathrm{~min}$, the entire sample turned light yellow, as demonstrated by sample S9 in Fig. 3a. It is worth mentioning that the sulfation roasting reaction was also characterized by the densification of the products, which means neck growth between the product particles.

The color change of the roasted samples was also accompanied by weight changes, characterized by weight increase $\Delta m$ and relative weight increase $\alpha$ 
(a)

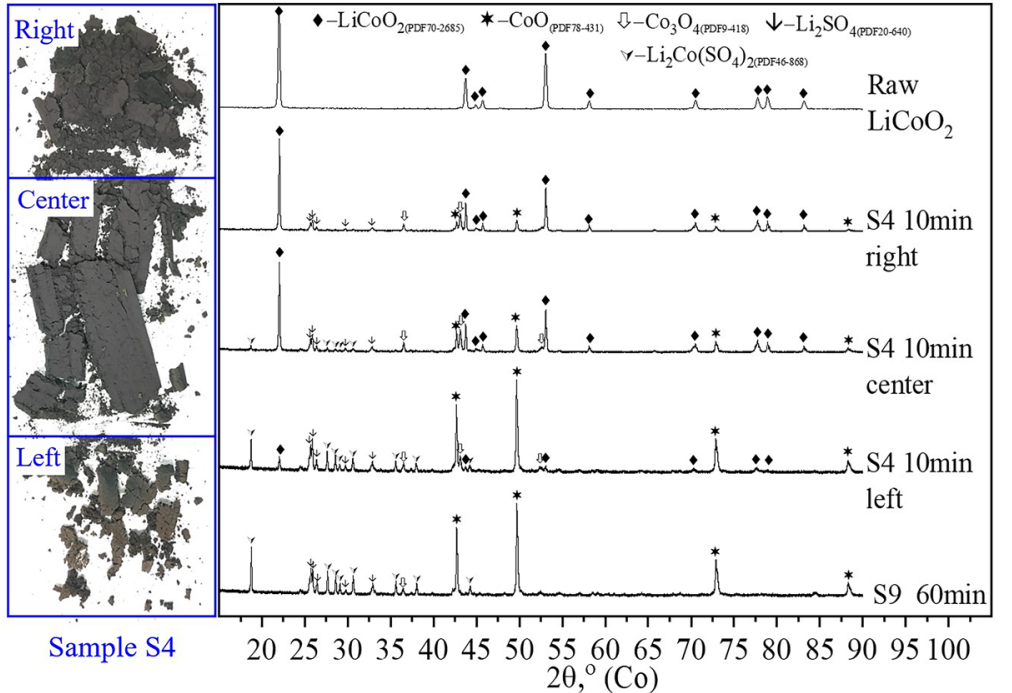

(c)

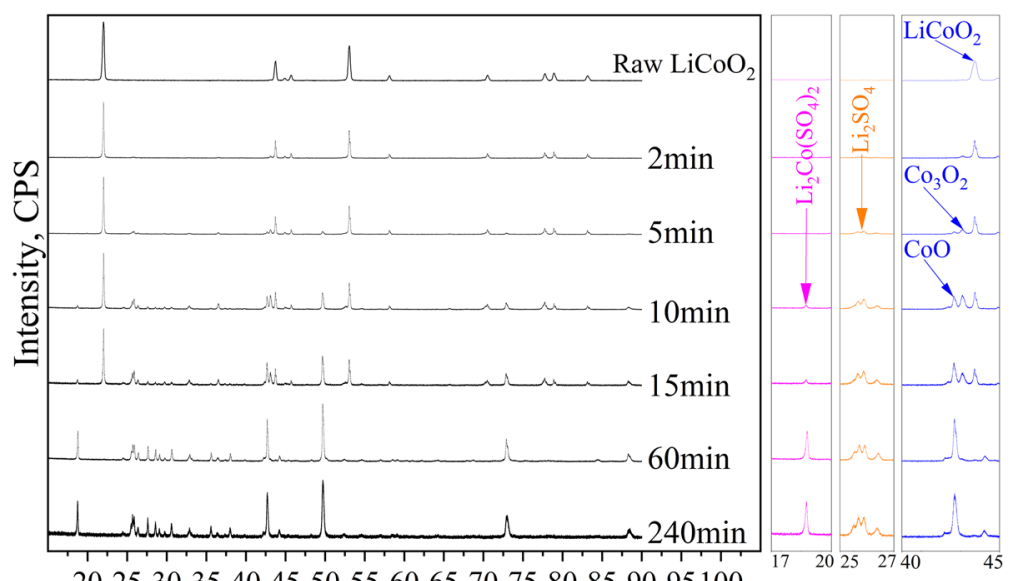

20253035404550556065707580859095100

$2 \theta,{ }^{\circ}(\mathrm{Co})$ (b)
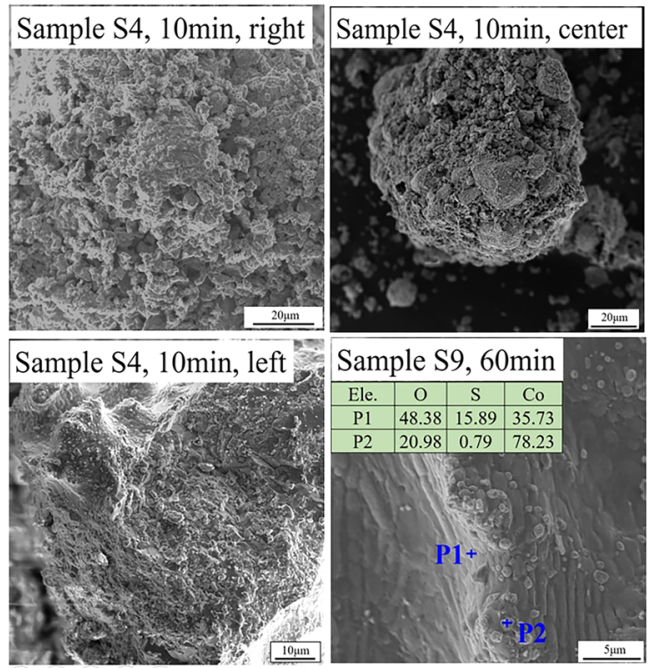

Sample S9, 60min

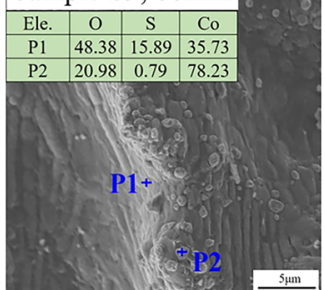

Fig. 4. Phase evolution and the corresponding microstructures characterized by XRD and SEM-EDS. (a) XRD patterns for the raw LiCoO 2 powder of samples S4 and S9 after sulfation roasting. (b) Microstructures for samples S4 and S9 after sulfation roasting; (c) XRD patterns for samples roasted from $2 \mathrm{~min}$ to $240 \mathrm{~min}$ at $700^{\circ} \mathrm{C}$.

in Fig. 3b. Figure 3b shows that the relative weight was rapidly increased from $3 \%$ at 2 min to $44 \%$ at $30 \mathrm{~min}$. Thereafter, there was only a small weight increase even if the roasting time was increased to 240 min, which implies that most of the sulfation reactions were completed during the first $30 \mathrm{~min}$. According to the experimental atmosphere of point A in Fig. 2, the final roasted products should be a blend of $\mathrm{Li}_{2} \mathrm{SO}_{4}+\mathrm{CoSO}_{4}$. This means the conversion $\beta$ should reach close to $100 \%$ when the time is extended beyond $30 \mathrm{~min}$. However, an interesting result is discovered when conversion $\beta$ along with time is plotted with reference to the final roasted products of $\mathrm{Li}_{2} \mathrm{SO}_{4}+\mathrm{CoSO}_{4}$; this is shown in Fig. 3c with the black squares. The highest conversion only can reach $44 \%$, even for $240 \mathrm{~min}$, and this inconsistency implies some other phases must be formed during roasting. To solve this confusion, a simple assumption with the final products of $\mathrm{Li}_{2} \mathrm{SO}_{4}+\mathrm{CoO}$ or $\mathrm{Li}_{2} \mathrm{SO}_{4}+\mathrm{Co}_{3} \mathrm{O}_{4}$ was used to calculate the conversion for comparison in Fig. 3c. Conversions $>100 \%$ were observed after $25 \mathrm{~min}$ for both assumptions, which indicates the final products were not simple combinations of $\mathrm{Li}_{2} \mathrm{SO}_{4}+\mathrm{CoO}$ or $\mathrm{Li}_{2} \mathrm{SO}_{4}+\mathrm{Co}_{3} \mathrm{O}_{4}$.

\section{Phase Evolution During Sulfation Roasting Reactions}

The existing phases and corresponding microstructures after sulfation roasting were characterized by XRD and SEM-EDS, as shown in detail in Fig. 4a, b, and c, respectively.

As observed in Fig. 3a, sulfation roasting gradually took place from the left to right side along with the gas flow direction, resulting in faster reactions on the left side than the right side of the crucible. 
Therefore, sample $\mathrm{S} 4$ reacted for $10 \mathrm{~min}$ and sample S9 reacted for 60 min were taken as examples to explore the phase assemblies during roasting. Sample S4 was divided into three sections and labeled as left, center, and right along with the gas flow direction, as shown in Fig. 4a. Compared with the XRD patterns of raw $\mathrm{LiCoO}_{2}$ powder, $\mathrm{Li}_{2} \mathrm{SO}_{4}$, $\mathrm{Co}_{3} \mathrm{O}_{4}$, and a small amount of $\mathrm{CoO}$ started to emerge in the right section of sample S4. In the center section of S4, binary sulfate of $\mathrm{Li}_{2} \mathrm{Co}\left(\mathrm{SO}_{4}\right)_{2}$ was formed. Meanwhile, the relative intensities of $\mathrm{Li}_{2} \mathrm{SO}_{4}, \mathrm{Co}_{3} \mathrm{O}_{4}$, and $\mathrm{CoO}$ became stronger, while the intensity of $\mathrm{LiCoO}_{2}$ got weaker, which indicated development of an increasing fraction of $\mathrm{Li}_{2} \mathrm{SO}_{4}$, $\mathrm{Co}_{3} \mathrm{O}_{4}$, and $\mathrm{CoO}$. Furthermore, in the left section of sample S4, it could be found that the relative intensities of $\mathrm{Li}_{2} \mathrm{SO}_{4}, \quad \mathrm{Li}_{2} \mathrm{Co}\left(\mathrm{SO}_{4}\right)_{2}$, and $\mathrm{CoO}$ increased, while the intensities of $\mathrm{LiCoO}_{2}$ and $\mathrm{Co}_{3} \mathrm{O}_{4}$ phase decreased. Thus, $\mathrm{Co}_{3} \mathrm{O}_{4}$ was first produced as an intermediate product and consumed thereafter. The corresponding SEM microstructures for sample S4 are shown in Fig. 4b. Many small particles were observed on the surfaces of a bigger matrix when the roasting reaction proceeded from the right to the left section.

In Fig. 4a, more complete sulfation roasting results are demonstrated by sample S9. The XRD patterns of S9 showed that when increasing the roasting time to $60 \mathrm{~min}$, there was no $\mathrm{LiCoO}_{2}$ left, and the final products were $\mathrm{Li}_{2} \mathrm{SO}_{4}, \mathrm{Li}_{2} \mathrm{Co}\left(\mathrm{SO}_{4}\right)_{2}$, $\mathrm{CoO}$, and a small amount of $\mathrm{Co}_{3} \mathrm{O}_{4}$. This is consistent with the trends of the results in sample S4. The microstructure for sample S9 in Fig. 4b also showed many small particles. However, an obvious difference was also observed in the phase matrix. Signs of melting compared with the particles in sample S4 were observed, and the EDS results indicated the matrix as the sulfate, while the particles were mostly $\mathrm{CoO}$, as shown in Fig. 4 b.

In Fig. 4c, XRD patterns for samples roasted in $10 \% \mathrm{SO}_{2}-1 \% \mathrm{O}_{2}-89 \% \mathrm{Ar}$ gas from 2 min to $240 \mathrm{~min}$ are plotted together for comparison. It can be concluded that with proceeding roasting reactions, the intensity of $\mathrm{LiCoO}_{2}\left(20^{\circ}-25^{\circ}\right)$ kept decreasing until the peaks fully disappeared. At the same time, the intensities of $\mathrm{Li}_{2} \mathrm{Co}\left(\mathrm{SO}_{4}\right)_{2}\left(17^{\circ}-20^{\circ}\right)$ and $\mathrm{Li}_{2} \mathrm{SO}_{4}$ $\left(25^{\circ}-27^{\circ}\right)$ became increasingly strong. However, the XRD patterns between $40^{\circ}$ and $45^{\circ}$ indicate that the intensity of $\mathrm{Co}_{3} \mathrm{O}_{4}$ was first increased and then decreased. The intensity of $\mathrm{CoO}\left(40^{\circ}-45^{\circ}\right)$ also became stronger, implying a spontaneous transformation from $\mathrm{Co}_{3} \mathrm{O}_{4}$ to $\mathrm{CoO}$. The XRD patterns from $40^{\circ}$ to $45^{\circ}$ also showed the intensity of $\mathrm{LiCoO}_{2}$ phase faded away. Therefore, the final products after sulfation roasting were confirmed as $\mathrm{Li}_{2} \mathrm{SO}_{4}$, $\mathrm{Li}_{2} \mathrm{Co}\left(\mathrm{SO}_{4}\right)$, and $\mathrm{CoO}$, and this explains why the conversion $\beta$ in Fig. $3 \mathrm{~b}$ was much lower with the assumption of $\mathrm{Li}_{2} \mathrm{SO}_{4}+\mathrm{CoSO}_{4}$ as the final product or much higher with the assumption of $\mathrm{Li}_{2} \mathrm{SO}_{4}+$ $\mathrm{CoO}$ and $\mathrm{Li}_{2} \mathrm{SO}_{4}+\mathrm{Co}_{3} \mathrm{O}_{4}$.

\section{Water Leaching}

The samples after sulfation roasting experiments were exposed to water leaching at $25^{\circ} \mathrm{C}$ for $60 \mathrm{~min}$. The leaching results are shown in Fig. 5a and b, respectively. As Fig. 5a shows, the leaching yield of $\mathrm{Li}$ significantly increased from $6 \%$ at $2 \mathrm{~min}$ to $99 \%$ at $30 \mathrm{~min}$, and $99.5 \% \mathrm{Li}$ was finally recovered in water when the roasting time increased to $120 \mathrm{~min}$. In contrast, the leaching efficiency of the cobalt element increased slowly, and only $17.4 \%$ Co was leached even after a roasting time of $120 \mathrm{~min}$.

The XRD patterns of roasted sample S4 and S9 in Fig. 5b showed that only the oxides were left in the leaching residue, which means that the sulfates of $\mathrm{Li}_{2} \mathrm{SO}_{4}$ and $\mathrm{Li}_{2} \mathrm{Co}\left(\mathrm{SO}_{4}\right)_{2}$ were leached by water. The corresponding SEM microstructures in Fig. 5b were demonstrated mainly as small particle phases, consistent with the microstructures found in Fig. 4$\mathrm{b}$, indicating that the matrix phase was dissolved in water. Furthermore, the quantitative calculation based on the intensities ${ }^{42}$ of the phases indicated that the unreacted $\mathrm{LiCoO}_{2}$ in the leaching residue dropped from $91 \%$ at $2 \mathrm{~min}$ to only $0.7 \%$ at $25 \mathrm{~min}$, as shown in Fig. 5c. At the same time, the content of $\mathrm{Co}_{3} \mathrm{O}_{4}$ in residue was first increased to $21 \%$ at $10 \mathrm{~min}$ and then decreased to $1 \%$ at $25 \mathrm{~min}$. Meanwhile, the $\mathrm{CoO}$ content continuously increased to $99.3 \%$ at $60 \mathrm{~min}$; this result is consistent with the XRD results for sample S4 in Fig. 4a.

\section{Mechanism of the Sulfation Roasting Reaction}

A significant discrepancy was found between the predicted and experimental result, as the calculated $\mathrm{CoSO}_{4}$ phase was not detected during sulfation roasting, while the detected $\mathrm{Li}_{2} \mathrm{Co}\left(\mathrm{SO}_{4}\right)_{2}$ phase was not considered in the calculations by HSC. The $\mathrm{Li}_{2} \mathrm{SO}_{4}-\mathrm{CoSO}_{4}$ binary phase diagram ${ }^{43-45}$ confirmed that $\mathrm{Li}_{2} \mathrm{Co}\left(\mathrm{SO}_{4}\right)_{2}$ phase is a double sulfate with an incongruent melting temperature of $610^{\circ} \mathrm{C}$. The reason why $\mathrm{Li}_{2} \mathrm{Co}\left(\mathrm{SO}_{4}\right)_{2}$ was identified in the present experimental conditions must be that $\mathrm{Li}_{2} \mathrm{Co}\left(\mathrm{SO}_{4}\right)_{2}$ becomes more stable in the higher partial pressure of a $\mathrm{SO}_{2}$ atmosphere compared with the $\mathrm{Ar}$ gas used for the determination of the $\mathrm{Li}_{2} \mathrm{SO}_{4}-\mathrm{CoSO}_{4}$ binary phase diagram. ${ }^{43-45}$ However, the thermodynamic data of $\mathrm{Li}_{2} \mathrm{Co}\left(\mathrm{SO}_{4}\right)_{2}$ were not available in the HSC software database.

Based on the end products and discussions above, the sulfation roasting reaction under $10 \% \mathrm{SO}_{2}-1 \%$ $\mathrm{O}_{2}-89 \%$ Ar gas mixture at $700^{\circ} \mathrm{C}$ can be described by the overall reaction $R 1$. The roasting mechanism can be further subdivided into three stages, as shown in Fig. 6.

$$
\begin{aligned}
& \text { Overall reaction: } 4 \mathrm{LiCoO}_{2}(\mathrm{~s})+3 \mathrm{SO}_{2}(\mathrm{~g})+\mathrm{O}_{2}(\mathrm{~g}) \\
& \quad=\mathrm{Li}_{2} \mathrm{SO}_{4}(\mathrm{~s})+\mathrm{Li}_{2} \mathrm{Co}\left(\mathrm{SO}_{4}\right)_{2}(\mathrm{~s})+3 \mathrm{CoO}(\mathrm{s})
\end{aligned}
$$



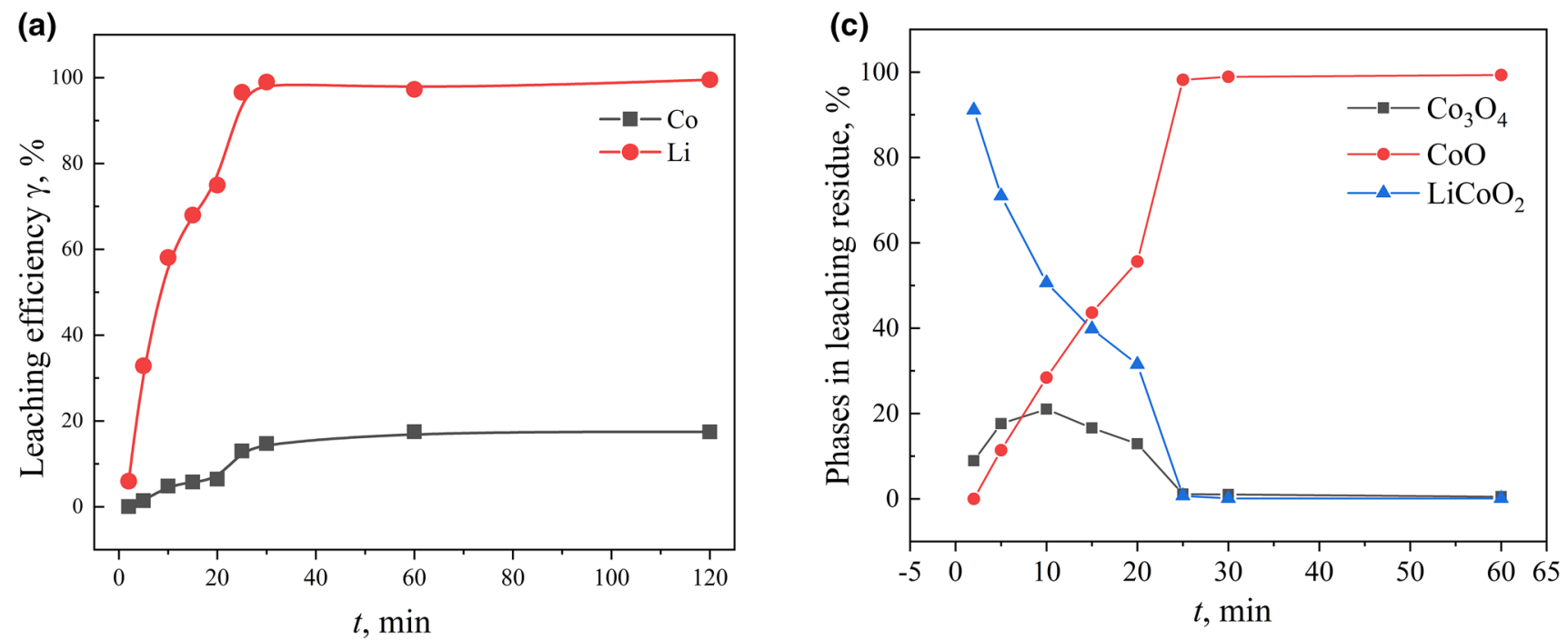

(b)
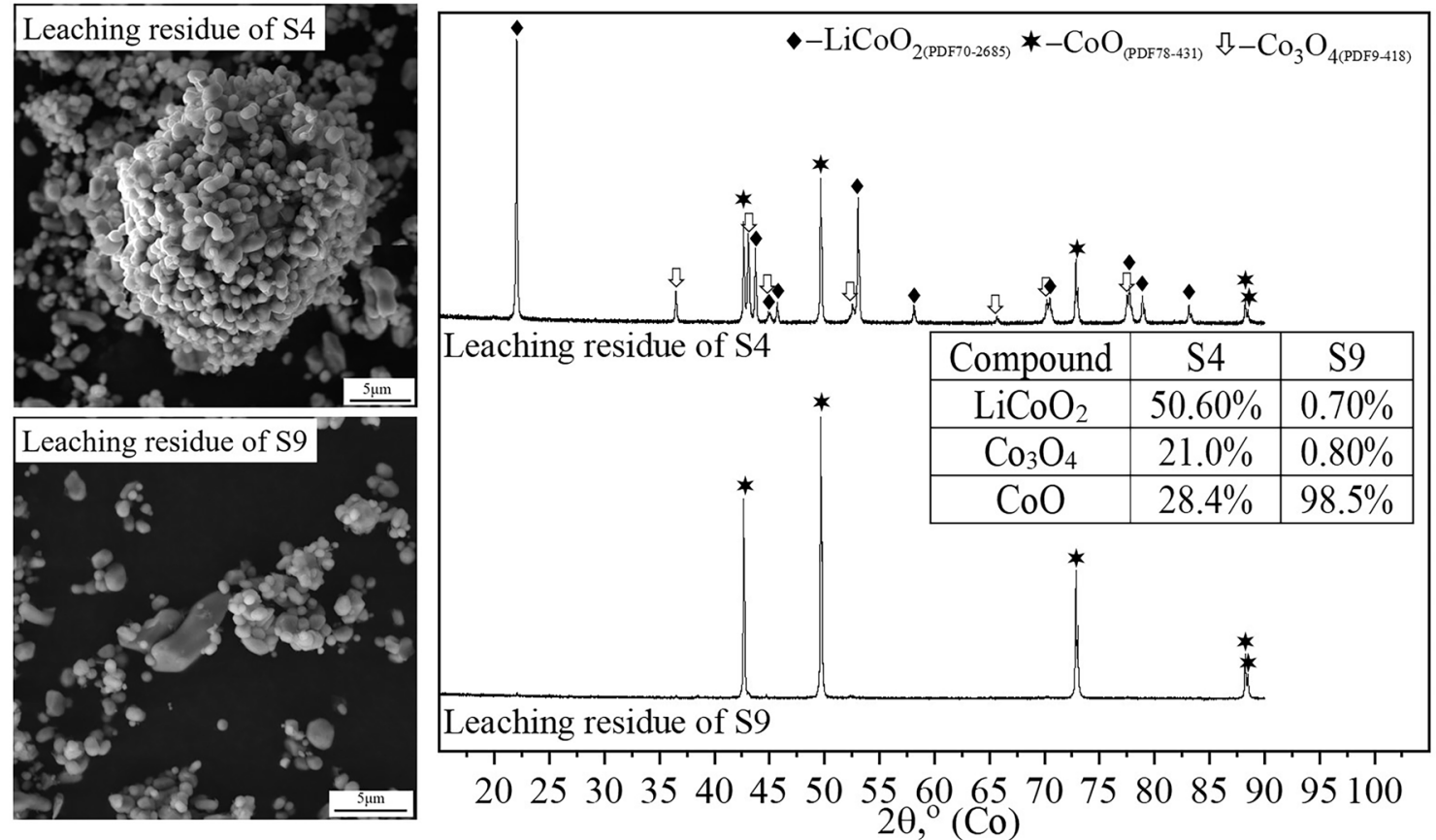

Fig. 5. Water leaching results. (a) Leaching efficiency for sulfation roasted samples from 2 min to $120 \mathrm{~min}$, \%; (b) XRD patterns and microstructures for leaching residues of samples S4 and S9; (c) different phases presented in leaching residues, \%.

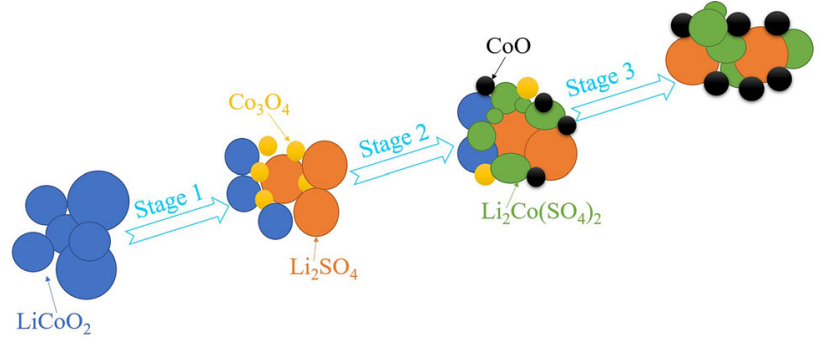

Fig. 6. Mechanism of sulfation roasting process under $10 \% \mathrm{SO}_{2}-1 \%$ $\mathrm{O}_{2}-89 \% \mathrm{Ar}$ gas at $700^{\circ} \mathrm{C}$
The first stage was mainly related to the production of $\mathrm{Co}_{3} \mathrm{O}_{4}$ and $\mathrm{Li}_{2} \mathrm{SO}_{4}$, and the related reactions in stage 1 are shown as (R2) to (R6). According to the relationship of $\Delta G^{\theta}\left(\mathrm{kJ} \mathrm{mol}^{-1}\right)$ with temperature $\left({ }^{\circ} \mathrm{C}\right)$ calculated by $\mathrm{HSC}$ in Fig. $7 \mathrm{a}, \mathrm{LiCoO}_{2}$ would not decompose to oxides by reactions $(R 2)$ and $(R 3)$ at $700^{\circ} \mathrm{C} . \mathrm{SO}_{3}$ was produced by reaction $(R 4)$, which made it feasible to transform $\mathrm{LiCoO}_{2}$ to $\mathrm{Li}_{2} \mathrm{SO}_{4}$ and $\mathrm{Co}_{3} \mathrm{O}_{4}$ by both the sulfation roasting reactions in $\mathrm{SO}_{2}-\mathrm{O}_{2}$ gas mixture [reaction (R5)] and $\mathrm{SO}_{3}$ gas [reaction (R6)]. During the second stage, the $\mathrm{Co}_{3} \mathrm{O}_{4}$ 

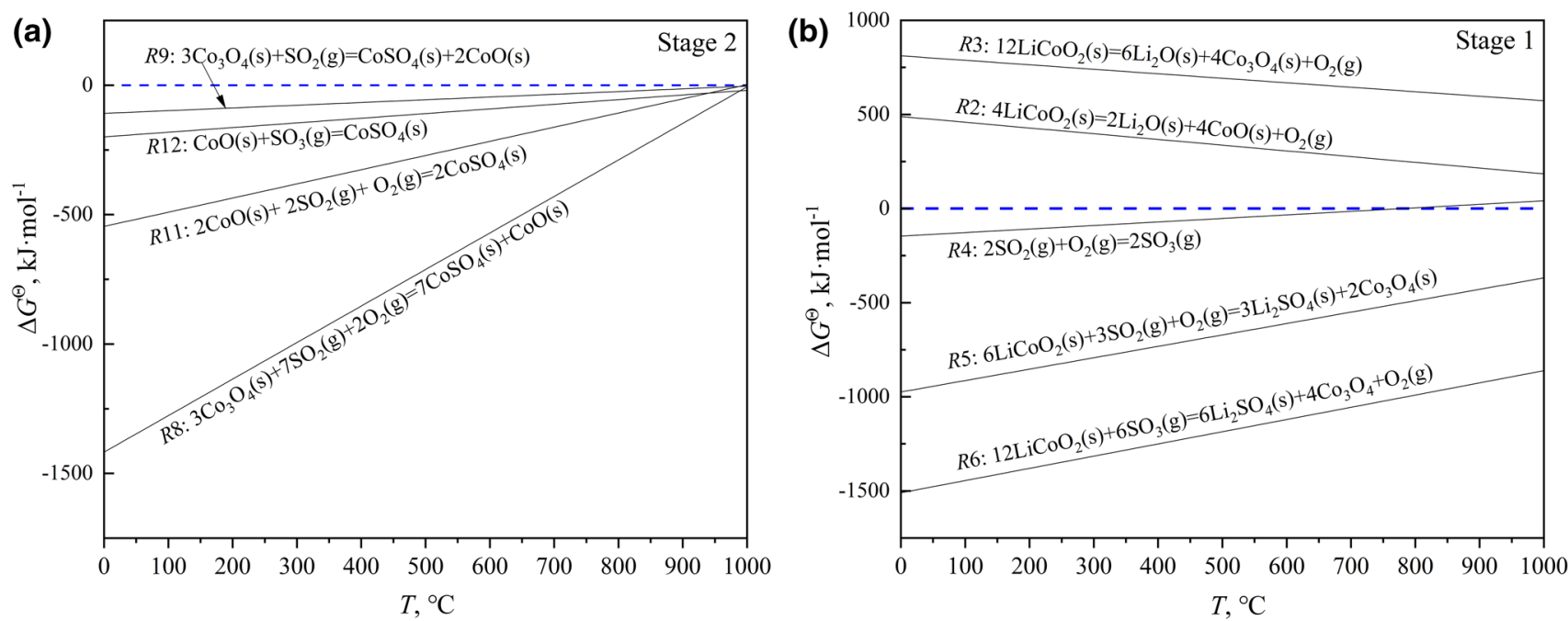

Fig. 7. Relationship between $\Delta G^{\theta}\left(\mathrm{kJ} \mathrm{mol}^{-1}\right)$ and temperature $\left(T,{ }^{\circ} \mathrm{C}\right)$ for different reactions $(R 2)$ to $(R 12)$. (a) Reactions taking place during stage 1: Gibbs energy of reaction versus temperature; ${ }^{41}$ (b) reactions taking place during stage 2: Gibbs energy of the reaction versus temperature ${ }^{41}$.

generated was consumed by the formation of $\mathrm{Li}_{2} \mathrm{Co}\left(\mathrm{SO}_{4}\right)_{2}$ and $\mathrm{CoO}$ with the overall reaction (R7). As there are no thermodynamic data for $\mathrm{Li}_{2} \mathrm{Co}\left(\mathrm{SO}_{4}\right)_{2}$, reactions $(R 8)$ to $(R 12)$ were then used as references to describe the process. As Fig. $7 \mathrm{~b}$ shows, $\mathrm{Co}_{3} \mathrm{O}_{4}$ was reduced to produce $\mathrm{CoO}$ and $\mathrm{CoSO}_{4}$ by either reaction (R8) or (R9), and the $\mathrm{CoSO}_{4}$ generated was combined with $\mathrm{Li}_{2} \mathrm{SO}_{4}$ to produce $\mathrm{Li}_{2} \mathrm{Co}\left(\mathrm{SO}_{4}\right)_{2}$ by reaction $(R 10)$. The subreactions $(R 8),(R 9)$, and $(R 10)$ were only used to better understand the roasting process. As no $\mathrm{CoSO}_{4}$ was detected during the roasting reactions, $\mathrm{Li}_{2} \mathrm{Co}\left(\mathrm{SO}_{4}\right)_{2}$ was believed to be formed directly by reaction (R7). The $\mathrm{CoO}$ generated may also have been sulfated by reactions $(R 11)$ and $(R 12)$ to produce $\mathrm{CoSO}_{4}$ and to accelerate the production of $\mathrm{Li}_{2} \mathrm{Co}\left(\mathrm{SO}_{4}\right)_{2}$. Finally, the sulfation roasting reactions would be completed in stage 3 to obtain the end products of $\mathrm{Li}_{2} \mathrm{SO}_{4}, \mathrm{Li}_{2} \mathrm{Co}\left(\mathrm{SO}_{4}\right)_{2}$, and $\mathrm{CoO}$. This is the reason for the conversion calculations in Fig. 3c. Based on the overall reaction ( $R 1)$, the conversion ratio was recalculated for a roasting time of $30 \mathrm{~min}$ to $240 \mathrm{~min}$, and the results are plotted together in Fig. 3c. The conversion ratio rapidly reached $90 \%$ for $30 \mathrm{~min}$ and then gradually increased close to $100 \%$ with a roasting time further increased beyond $30 \mathrm{~min}$.

Stage $1\left(\Delta G^{\theta}\right.$ in kJ mol ${ }^{-1}$, temperature $T$ in $\left.{ }^{\circ} \mathrm{C}\right)$

$$
\begin{gathered}
4 \mathrm{LiCoO}_{2}(\mathrm{~s})=2 \mathrm{Li}_{2} \mathrm{O}(\mathrm{s})+4 \mathrm{CoO}(\mathrm{s})+\mathrm{O}_{2}(\mathrm{~g}) \\
\Delta G^{\theta}=489.00476-0.30411 T[41]
\end{gathered}
$$

$$
\begin{gathered}
12 \mathrm{LiCoO}_{2}(\mathrm{~s})=6 \mathrm{Li}_{2} \mathrm{O}(\mathrm{s})+4 \mathrm{Co}_{3} \mathrm{O}_{4}(\mathrm{~s})+\mathrm{O}_{2}(\mathrm{~g}) \\
\Delta G^{\theta}=811.59349-0.23849 T[41]
\end{gathered}
$$

$$
\begin{aligned}
& 2 \mathrm{SO}_{2}(\mathrm{~g})+\mathrm{O}_{2}(\mathrm{~g})=2 \mathrm{SO}_{3}(\mathrm{~g}) \\
& \quad \Delta G^{\theta}=-146.2697+0.18775 T[41]
\end{aligned}
$$

$$
\begin{aligned}
& 6 \mathrm{LiCoO}_{2}(\mathrm{~s})+3 \mathrm{SO}_{2}(\mathrm{~g})+\mathrm{O}_{2}(\mathrm{~g}) \\
& =3 \mathrm{Li}_{2} \mathrm{SO}_{4}(\mathrm{~s})+2 \mathrm{Co}_{3} \mathrm{O}_{4}(\mathrm{~s}) \\
& \Delta G^{\theta}=-974.36564+0.60604 T[41] \\
& 12 \mathrm{LiCoO}_{2}(\mathrm{~s})+6 \mathrm{SO}_{3}(\mathrm{~g}) \\
& \quad=6 \mathrm{Li}_{2} \mathrm{SO}_{4}(\mathrm{~s})+4 \mathrm{Co}_{3} \mathrm{O}_{4}(\mathrm{~s})+\mathrm{O}_{2}(\mathrm{~g})
\end{aligned}
$$$$
\Delta G^{\theta}=-1509.92219+0.64882 T[41]
$$

Stage 2

$$
\begin{aligned}
& 3 \mathrm{Co}_{3} \mathrm{O}_{4}(\mathrm{~s})+7 \mathrm{SO}_{2}(\mathrm{~g})+2 \mathrm{O}_{2}(\mathrm{~g})+7 \mathrm{Li}_{2} \mathrm{SO}_{4}(\mathrm{~s}) \\
& =7 \mathrm{Li}_{2} \mathrm{Co}\left(\mathrm{SO}_{4}\right)_{2}(\mathrm{~s})+\mathrm{CoO}(\mathrm{s})(R 7) \\
& 3 \mathrm{Co}_{3} \mathrm{O}_{4}(\mathrm{~s})+7 \mathrm{SO}_{2}(\mathrm{~g})+2 \mathrm{O}_{2}(\mathrm{~g}) \\
& \quad=7 \mathrm{CoSO}_{4}(\mathrm{~s})+\mathrm{CoO}(\mathrm{s}) \\
& \Delta G^{\theta}=-1417.82422+1.4114 T[41] \\
& 3 \mathrm{Co}_{3} \mathrm{O}_{4}(\mathrm{~s})+\mathrm{SO}_{2}(\mathrm{~g})=\mathrm{CoSO}_{4}(\mathrm{~s})+2 \mathrm{CoO}(\mathrm{s}) \\
& \Delta G^{\theta}=-108.91481+0.10537 T[41]
\end{aligned}
$$

$$
\mathrm{Li}_{2} \mathrm{SO}_{4}(\mathrm{~s})+\mathrm{CoSO}_{4}(\mathrm{~s})=\mathrm{Li}_{2} \mathrm{Co}\left(\mathrm{SO}_{4}\right)_{2}(\mathrm{~s})
$$




$$
\begin{gathered}
2 \mathrm{CoO}(\mathrm{s})+2 \mathrm{SO}_{2}(\mathrm{~g})+\mathrm{O}_{2}(\mathrm{~g})=2 \mathrm{CoSO}_{4}(\mathrm{~s}) \\
\Delta G^{\theta}=-545.53989+0.54765 T[41] \\
\mathrm{CoO}(\mathrm{s})+\mathrm{SO}_{3}(\mathrm{~g})=\mathrm{CoSO}_{4}(\mathrm{~s}) \\
\Delta G^{\theta}=-199.6351+0.17995 T[41]
\end{gathered}
$$

\section{CONCLUSION}

Sulfation roasting followed by water leaching has been proposed for the recycling of spent LIBs. The reaction mechanism was studied by the roasting of synthetic $\mathrm{LiCoO}_{2}$ powder in $10 \% \mathrm{SO}_{2}-1 \% \mathrm{O}_{2}-89 \% \mathrm{Ar}$ gas atmosphere at $700^{\circ} \mathrm{C}$. The reaction patterns and corresponding microstructures were analyzed by XRD and SEM-EDS, while the $\mathrm{Li}$ and Co contents in the pregnant solution were characterized by AAS analysis. Based on the experimental results, the reaction mechanism under the present experimental condition was concluded as follows: $\mathrm{LiCoO}_{2}$ powder was first converted to $\mathrm{Li}_{2} \mathrm{SO}_{4}$ and $\mathrm{Co}_{3} \mathrm{O}_{4}$; the produced $\mathrm{Co}_{3} \mathrm{O}_{4}$ was further reduced as $\mathrm{CoO}$ or combined with $\mathrm{Li}_{2} \mathrm{SO}_{4}$ to form $\mathrm{Li}_{2} \mathrm{Co}\left(\mathrm{SO}_{4}\right)_{2}$. In the end, the products of $\mathrm{Li}_{2} \mathrm{SO}_{4}, \mathrm{Li}_{2} \mathrm{Co}\left(\mathrm{SO}_{4}\right)_{2}$, and $\mathrm{CoO}$ were obtained. The experimental results were quite different from the thermodynamic predictions where $\mathrm{Li}_{2} \mathrm{SO}_{4}$ and $\mathrm{CoSO}_{4}$ were calculated as the final products, as $\mathrm{Li}_{2} \mathrm{Co}\left(\mathrm{SO}_{4}\right)_{2}$ was not presented in the database. The achieved results suggest that sulfation roasting can provide a method for direct leaching of $\mathrm{Li}$ for improved Li recovery from battery waste. However, only $17.4 \%$ of Co could be extracted into the water, indicating a need for consequent development of an acid leaching process. The results from the present work are not only important for recycling of spent LIBs, but also can serve as a basis for the thermodynamic modeling of an Li-Co-O-S system. Moreover, the experimental results can also provide a method for consuming the $\mathrm{SO}_{2}$ gas generated from metallurgical smelting processes, e.g., the copper matte converting process.

\section{ACKNOWLEDGEMENTS}

Open access funding provided by Aalto University. This work was financed by the Aalto University School of Chemical Engineering and utilized the Academy of Finland's RawMatTERS Finland Infrastructure (RAMI), based jointly at Aalto University, GTK Espoo, and VTT Espoo.

\section{OPEN ACCESS}

This article is distributed under the terms of the Creative Commons Attribution 4.0 International License (http://creativecommons.org/licenses/by/ 4.0/), which permits unrestricted use, distribution, and reproduction in any medium, provided you give appropriate credit to the original author(s) and the source, provide a link to the Creative Commons license, and indicate if changes were made.

\section{REFERENCES}

1. W. Haas, F. Krausmann, D. Wiedenhofer, and M. Heinz, J. Ind. Ecol. 19, 765 (2015).

2. G.E. Blomgren, J. Electrochem. Soc. 164, A5019 (2017).

3. W. Bernhart, ATZ Electron. Worldw. 14, 38 (2019).

4. X. Zhang, L. Li, E. Fan, Q. Xue, Y. Bian, F. Wu, and R. Chen, Chem. Soc. Rev. 47, 7239 (2018).

5. X. Zeng and J. Li, Front. Environ. Sci. Eng. 8, 792 (2014).

6. R. Golmohammadzadeh, F. Faraji, and F. Rashchi, Resour. Conserv. Recycl. 136, 418 (2018).

7. T.S. Yusupov, V.P. Isupov, A.G. Vladimirov, V.E. Zagorsky, E.A. Kirillova, L.G. Shumskaya, and N.Z. Lyakhov, J. Min. Sci. 51, 1242 (2015).

8. S.M. Shin, N.H. Kim, J.S. Sohn, D.H. Yang, and Y.H. Kim, Hydrometallurgy 79, 172 (2005).

9. S. Natarajan and V. Aravindan, ACS Energy Lett. 3, 2101 (2018).

10. D.H.P. Kang, M. Chen, and O.A. Ogunseitan, Environ. Sci. Technol. 47, 5495 (2013).

11. H. Aral and A. Vecchio-Sadus, Ecotoxcol. Environ. Saf. 70, 349 (2008)

12. W.Q. Zhuang, J.P. Fitts, C.M. Ajo-Franklin, S. Maes, L. Alvarez-Cohen, and T. Hennebel, Curr. Opin. Biotechnol. 33, 327 (2015).

13. C. Peng, J. Hamuyuni, B.P. Wilson, and M. Lundström, Waste Manag. 76, 582 (2018).

14. Y. Yang, G. Huang, S. Xu, Y. He, and X. Liu, Hydrometallurgy 165, 390 (2016).

15. J. Diekmann, C. Hanisch, L. Froböse, G. Schälicke, T. Loellhoeffel, A.S. Fölster, and A. Kwade, J. Electrochem. Soc. 164, A6184 (2017).

16. J. Zhang, J. Hu, W. Zhang, Y. Chen, and C. Wang, J. Clean. Prod. 204, 437 (2018).

17. A. Porvali, M. Aaltonen, S. Ojanen, O. Velazquez-Martinez, E. Eronen, F. Liu, and M. Lundström, Resour. Conserv. Recycl. 142, 257 (2019).

18. C. Peng, F. Liu, Z. Wang, B.P. Wilson, and M. Lundström, J. Power Sources 415, 179 (2019).

19. E.G. Pinna, M.C. Ruiz, M.W. Ojeda, and M.H. Rodriguez, Hydrometallurgy 167, 66 (2017).

20. C.S. Dos Santos, J.C. Alves, S.P. da Silva, L.E. Sita, P.R.C. da Silva, L.C. de Almeida, and J. Scarminio, J. Hazard. Mater. 362, 458 (2019).

21. L. Yao, H. Yao, G. Xi, and Y. Feng, $R S C A d v .6,17947$ (2016).

22. J. Nan, D. Han, and X. Zuo, J. Power Sources 152, 278 (2005).

23. L. Zhang, D. Shi, L. Li, X. Peng, F. Song, and H. Rui, J. Mol. Liq. 274, 746 (2019).

24. X. Zeng and J. Li, J. Hazard. Mater. 271, 50 (2014).

25. W. Lv, Z. Wang, H. Cao, Y. Sun, Y. Zhang, and Z. Sun, ACS Sustain. Chem. Eng. 6, 1504 (2018).

26. J. Xiao, J. Li, and Z. Xu, J. Hazard. Mater. 338, 124 (2017).

27. G.X. Ren, S.W. Xiao, M.Q. Xie, P.A.N. Bing, C.H.E.N. Jian, F.G. Wang, and X.I.A. Xing, Trans. Nonferr. Metal. Soc. 27, 450 (2017)

28. H. Dang, B. Wang, Z. Chang, X. Wu, J. Feng, H. Zhou, and C. Sun, ACS Sustain. Chem. Eng. 6, 13160 (2018).

29. D. Wang, X. Zhang, H. Chen, and J. Sun, Miner. Eng. 126, $28(2018)$

30. J. Hu, J. Zhang, H. Li, Y. Chen, and C. Wang, J. Power Sources 351, 192 (2017).

31. T. Träger, B. Friedrich, and R. Weyhe, Chem. Ing. Tech. 87, 1550 (2015).

32. Y.X. Zheng, W. Liu, W.Q. Qin, J.W. Han, K. Yang, H.L. Luo, and D.W. Wang, Can. Metall. Q. 54, 92 (2015).

33. L.E.K. Holappa, Acta Polytech. Scand. Chem. Incl. Metall. Ser. 92, 1 (1970).

34. X. Li and B. Xie, Int. J. Min. Met. Mater. 19, 595 (2012).

35. T.R. Ingraham and R. Kerby, Can. Metall. Q. 6, 89 (1967). 
36. D. Wang, H. Wen, H. Chen, Y. Yang, and H. Liang, Chem. Res. Chin. Univ. 32, 674 (2016).

37. K.T. Jacob, R. Akila, and A.K. Shukla, J. Solid. State Chem. 69, 109 (1987).

38. B.H. Toby, J. Appl. Crystallogr. 38, 1040 (2005).

39. C. Merlet, Microchim. Acta 114, 363 (1994).

40. C. Pickles and O. Marzoughi, Minerals 9, 18 (2019).

41. A. Roine, HSC Chemistry for Windows, vers. 9.2.6 (Pori, Finland: Outotec Research, 2019). www.hsc-chemistry.com. Accessed 25 June 2019.

42. C.R. Hubbard and R.L. Snyder, Powder Diffr. 3, 74 (1988).
43. M. Touboul, P. Edern, F. Broszniowski, and E. Bétourné, Solid State Ion. 50, 323 (1992).

44. M. Touboul, E. Le Samedi, N. Sephar, F. Broszniowski, P. Edern, and E. Bétourné, J. Therm. Anal. Calorim. 40, 1151 (1993).

45. A.V. Radha, L. Lander, G. Rousse, J.M. Tarascon, and A. Navrotsky, J. Mater. Chem. A 3, 2601 (2015).

Publisher's Note Springer Nature remains neutral with regard to jurisdictional claims in published maps and institutional affiliations. 